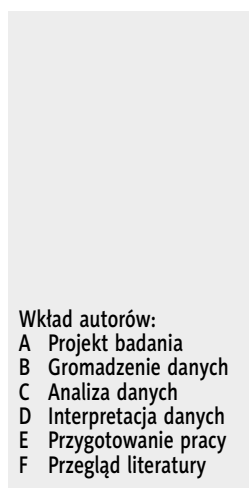

\title{
Narzędzia do oceny znajomości języka migowego u dzieci - przegląd
}

\section{Sign language assessment tools for children - a review}

\author{
Anna Wiśniewska-Jankowska ${ }^{\text {BDEF }}$
}

Zespół Poradni Psychologiczno-Pedagogicznych nr 2, Poznań

\section{Streszczenie}

W artykule dokonano przeglądu przykładowych, tworzonych w Ameryce Północnej oraz Europie, narzędzi do oceny poziomu znajomości języka migowego u dzieci, w celu pokazania głównych założeń, którymi kierują się ich twórcy. Istniejące narzędzia zostały podzielone na dwie kategorie: skale obserwacyjne i testy kompetencji. Skale obserwacyjne pogrupowano w zależności od zakresu możliwej do przeprowadzenia za ich pomocą oceny poziomu funkcjonowania językowego dzieci. Zaproponowano również kategoryzacje testów kompetencji w oparciu o dwa kryteria - rodzaj ocenianych sprawności językowych oraz zakres materiału językowego poddawanego analizie. Słowa kluczowe: ocena znajomości języka migowego • rozwój języka migowego • testy do oceny znajomości języka migowego u dzieci

\section{Abstrakt}

This article reviews examples of tools, created in North America and Europe, for assessment of the level of sing-language linguistic competence among children, in order to demonstrate the main objectives of their authors. The existing tools were divided into two categories: assessment scales and proficiency tests. The assessment scales were further grouped depending on the scope of children's linguistic functioning assessment possible to be made when using them. The article follows with a suggestion for a categorization of the proficiency tests based on the basis of two criteria: type of language skills being assessed and the range of linguistic material subjected analysis.

Keywords: sign language assessment $\bullet$ sign language development $\bullet$ sign language tests for children

Wykaz skrótów:

\begin{tabular}{lc}
\hline Skrót & Rozwinięcie w języku oryginalnym \\
\hline ASL & American Sign Language \\
\hline ASLAI & American Sign Language Assessment Instrument \\
\hline ASL-CDI & $\begin{array}{c}\text { MacArthur Communicative Development } \\
\text { Inventory for American Sign Language }\end{array}$ \\
\hline ASL-PA & American Sign Language Proficiency Assessment \\
\hline ATG & $\begin{array}{c}\text { Aachen Tests zur Basiskompetenz } \\
\text { in Deutscher Gebärdensprache }\end{array}$ \\
\hline BSL & British Sign Language \\
\hline BSL-PT & British Sign Language Production Test \\
\hline BSL-RST & British Sign Language Receptive Skill Test \\
\hline BSL-VT & Web-based British Sign Language Vocabulary Test \\
\hline C-PhAT- & Cross-modal Phonological Awareness Test \\
SSL & for Swedish Sign Language \\
\hline
\end{tabular}

\begin{tabular}{lc}
\hline Skrót & Rozwinięcie w języku oryginalnym \\
\hline CTDGS & $\begin{array}{c}\text { Computer-based Test } \\
\text { for German Sign Language }\end{array}$ \\
\hline DGS & Deutsche Gebärdensprache \\
\hline LPP-2 & Language Proficiency Profile-2 \\
\hline NGT-OP & NGT-Observatiepakket \\
\hline PERLESKO & $\begin{array}{c}\text { Prüfverfahren zur Erfassung } \\
\text { lexikalisch-semantischer Kompeten }\end{array}$ \\
\hline PMLP & Profile of Multiple Language Proficiencies \\
\hline TASL & Test of American Sign Language \\
\hline TNGT & $\begin{array}{r}\text { Testbatterij voor de Nederlandse } \\
\text { Gebarentaal }\end{array}$ \\
\hline VCSL & $\begin{array}{r}\text { Visual Communication and Sign Language } \\
\text { Checklist (for Deaf and Hard } \\
\text { of Hearing Children) }\end{array}$ \\
\hline
\end{tabular}

Adres autora: Anna Wiśniewska-Jankowska, Zespół Poradni Psychologiczno-Pedagogicznych nr 2, ul. 28 czerwca 1956 r. nr 296/298, 61-469 Poznań, e-mail: wisniewska.anka@gmail.com 


\section{Wstęp}

Począwszy od lat 90. XX wieku, w coraz większej liczbie specjalistycznych opracowań, można zaobserwować tendencję do przedstawiania głuchoty jako czynnika modyfikującego warunki rozwoju jednostki, a nie upośledzającego ją [1]. Jednym z elementów wskazywanych jako potencjalnie odróżniające osoby niesłyszące od populacji ogólnej jest ich ekspozycja na język migowy. Zaczęto dostrzegać ogromną rolę, jaką język migowy może odgrywać w rozwoju procesów poznawczych jednostki, a w następstwie - podejmować działania, których celem było stworzenie narzędzi umożliwiających różnicowanie poziomu znajomości języka migowego wśród jego użytkowników oraz monitorowanie rozwoju poszczególnych elementów składowych języka (w tym m.in. słownictwa, struktury, gramatyki itd.) u dzieci [2]. Pierwsze narzędzia zostały opracowane w latach 90 . XX wieku w Stanach Zjednoczonych i Holandii. Z biegiem lat kolejne ośrodki podejmowały tego typu prace. Stopniowo zaczęto jednak różnicować cele tworzenia poszczególnych narzędzi. Poza testami oceniającymi poziom rozwoju języka migowego jako języka pierwszego lub języka obcego, zaczęto także tworzyć narzędzia służące do prowadzenia badań lingwistycznych nad językami migowymi oraz do analizy funkcjonowania procesów poznawczych u osób posługujących się językiem migowym [3].

W dalszej części artykułu scharakteryzowano przykładowe narzędzia, które służą przede wszystkim do oceny znajomości języka migowego u najmłodszych, uznając je za najbardziej przydatne z perspektywy codziennej praktyki klinicznej. Narzędzia te zostały przedstawione i omówione przy zastosowaniu podziału na dwie główne kategorie - skale obserwacyjne i testy kompetencji. Następnie skale obserwacyjne zostały pogrupowane w zależności od zakresu oceny poziomu funkcjonowania językowego dziecka, którą można za ich pomocą przeprowadzić. W przypadku testów kompetencji zaproponowano dwa sposoby ich kategoryzowania według: a) rodzaju ocenianych sprawności językowych oraz b) zakresu materiału językowego poddawanego analizie. Celem niniejszego opracowania nie będzie jednak przedstawienie wszystkich powstałych do tej pory narzędzi, a jedynie pokazanie na wybranych przykładach tendencji, które można zaobserwować wśród ich twórców, działających w obszarze zachodniego kręgu kulturowego.

Ponadto szczególnie ważne wydaje się zwrócenie uwagi polskiego czytelnika na potrzebę konstruowania tego rodzaju narzędzi diagnostycznych, ponieważ w naszym kraju do tej pory nie powstały żadne kwestionariusze, skale czy ankiety do oceny znajomości polskiego języka migowego (PJM), które mogłyby być wykorzystywane w codziennej praktyce diagnostycznej. Podejmowane do tej pory prace, m.in. nad polską adaptacją British Sign Language Receptive Skill Test (BSL-RST) [4] oraz autorskim Testem do Oceny Znajomości Leksyki w Polskim Języku Migowym (TOZL-PJM) [5], są na etapie badań i nie wiadomo, kiedy wspomniane testy będą mogły znaleźć szersze zastosowanie.

\section{Skale obserwacyjne}

Skale obserwacyjne mają najczęściej formę list z wyszczególnionymi umiejętnościami w zakresie formułowania i rozumienia zróżnicowanych komunikatów językowych. W zależności od zakresu możliwej do przeprowadzenia za ich pomocą oceny można je podzielić na dwie grupy: skale służące do oceny tylko i wyłącznie funkcjonowania dziecka w zakresie języka migowego oraz skale umożliwiające dokonywanie całościowej oceny funkcjonowania jednostki (uwzględniające zarówno język migowy, jak i umiejętności posługiwania się gestami, językiem fonicznym w mowie i/lub piśmie itp.). Od testów kompetencji skale obserwacyjne odróżnia między innymi to, że proces oceny dokonywany jest na podstawie obserwacji prowadzonej w naturalnym środowisku dziecka, bez wykorzystywania jakichkolwiek materiałów testowych.

W chwili obecnej najbardziej rozbudowaną i jedyną skalą obserwacyjną, która została znormalizowana i udostępniona do użytku powszechnego, jest VCSL (ang. Visual Communication and Sign Language Checklist). Opracowały ją L. Simms, S. Baker i M.D. Clarke w ramach Science of Learning Center Visual Language and Visual Learning: VL2 na Uniwersytecie Gallaudeta (USA). Narzędzie to funkcjonuje na rynku od 2013 roku (w formie papierowej) [6], a od 2016 jest dostępne za pośrednictwem platformy internetowej [7]. VCSL jest przeznaczone do oceny poziomu rozwoju językowego dzieci głuchych od urodzenia do 5 roku życia, w zakresie amerykańskiego języka migowego (ang. American Sign Language, ASL). Skalę podzielono na 5 części ze względu na wiek dzieci: od 0 do 1. roku życia, od 1. do 2. roku życia, od 2. do 3 . roku życia, od 3. do 4. roku życia, od 4. do 5. roku życia. Każda z części ma formę listy sprawności językowych (zarówno w zakresie rozumienia, jak i formułowania komunikatów językowych), które dziecko powinno posiadać na danym etapie rozwoju. Zadaniem osoby lub osób prowadzących obserwację dziecka jest rozstrzygnięcie, czy: a) dziecko bardzo dobrze opanowało (ang. mastered) posługiwanie się daną konstrukcją językową, b) tylko czasami posługuje się nią poprawnie (ang. inconsistent use), c) dana konstrukcja jest przez dziecko jedynie sporadycznie wykorzystywana/rozumiana (ang. emerging), d) w ogóle nie jest ona w jego użyciu, a więc jej jeszcze nie przyswoiło (ang. not yet emerging).

Zgodnie z założeniami twórców VCSL podstawą do określenia stopnia opanowania przez dziecko danej umiejętności ma być stała obserwacja jego zachowań językowych w codziennych sytuacjach życiowych. Formularz VCSL powinien być zatem $\mathrm{z}$ założenia wypełniany przez osoby, które mają częsty kontakt $\mathrm{z}$ dzieckiem i bardzo dobrze znają język migowy. Jako że nie zawsze osoby spędzające najwięcej czasu z dzieckiem posiadają adekwatny poziom znajomości języka migowego do dokonywania tego typu oceny, autorzy narzędzia zalecają prowadzenie obserwacji w kilkuosobowych zespołach - np. osoby niesłyszące lub słabosłyszące (znające język migowy na bardzo wysokim poziomie) mogą pomagać rodzicom, nauczycielom, logopedom i in. (posiadającym niższe kompetencje w posługiwaniu się tym językiem).

Skala VCSL została stworzona z myślą o dzieciach, dla których język migowy (w tym przypadku ASL) był językiem pierwszym (ang. native language), czyli dla jego natywnych użytkowników, i znormalizowana na podstawie badań przeprowadzonych w tej grupie. Twórcy narzędzia 
dopuszczają jednak wykorzystanie VCSL także w celu oceny poziomu funkcjonowania językowego dzieci, które zetknęły się z nim na późniejszych etapach swojego życia. W przypadku badania nienatywnych użytkowników ASL możliwe jest porównanie oceny poziomu funkcjonowania językowego badanego dziecka $\mathrm{z}$ jego natywnymi użytkownikami. Ocenie za pomocą VCSL mogą być również poddawane dzieci powyżej 5 roku życia, u których podejrzewa się występowanie zaburzeń/opóźnień w zakresie rozwoju językowego. Jest to zatem narzędzie posiadające szerokie zastosowanie kliniczne [6].

Skalą rozwojową skonstruowaną również z myślą o dzieciach wywodzących się z głuchych rodzin była MacArthur Communicative Development Inventory for American Sign Language (ASL-CDI), powstała kilkanaście lat przed VCSL. Opracowały ją D. Anderson i J. Reilly. ASL-CDI stanowi adaptację English Communicative Development Inventory $\mathrm{i}$ jest skalą obserwacyjną, którą z założenia mają wypełniać głusi rodzice - co ważne, komunikujący się za pomocą języka migowego. Służy ona do oceny funkcjonowania dzieci w wieku 8-36 miesięcy, będących natywnymi użytkownikami ASL. Jako że ASL-CDI może być wykorzystywana do badania dzieci, które nie ukończyły trzeciego roku życia, pozwala ona ocenić mniej obszarów funkcjonowania językowego niż VCSL, która obejmuje okres pierwszych pięć lat życia dziecka. Skala ASL-CDI nie stała się nigdy powszechnie dostępna, mimo że jest to narzędzie znormalizowane [8].

Warto również zauważyć, że skale obserwacyjne, które zostały znormalizowane na podstawie badań przeprowadzonych w populacji dzieci głuchych będących natywnymi użytkownikami języka migowego, stanowią nie tylko wartościowe narzędzia diagnostyczne, lecz także - co często podkreślają ich autorzy - przyczyniają się do poszerzania wiedzy na temat kolejności przyswajania przez dzieci poszczególnych elementów składowych języka [6,8].

Poza znormalizowanymi skalami obserwacyjnymi istnieją również narzędzia opracowywane na podstawie wiedzy teoretycznej na temat opanowywania przez dzieci kolejnych struktur języka migowego. Przykładem tego typu skali obserwacyjnej, przygotowanej dla innego niż ASL języka migowego, jest holenderska NGT-Observatiepakket (NGT-OP) autorstwa A. Baker i S. Jansmy. Narzędzie to jest przeznaczone do diagnozowania/badania dzieci w wieku 2,6-4 lata (dopuszczane jest również jego użycie w przypadku dzieci do 7. roku życia, a nawet starszych).

Zgodnie z założeniami autorów NGT-OP powinna być wypełniana przez nauczycieli uczących dziecko na podstawie wiedzy na jego temat $\mathrm{z}$ okresu ostatnich 3 miesięcy. Holenderska skala do tej pory nie została jednak znormalizowana oraz oficjalnie opublikowana. $\mathrm{Z}$ powodu braku norm nie jest również możliwe określenie poziomu rozwoju językowego dziecka przy jej użyciu. Za jej pomocą można jednak monitorować rozwój językowy dziecka - porównywać wyniki uzyskiwane przez nie w trakcie kolejnych ewaluacji [9]. Możliwość śledzenia czynionych przez dziecko postępów jest jedną z głównych zalet narzędzi tworzonych bez przeprowadzania badań normalizacyjnych, takich jak wspomniana skala NGT-OP czy też różnego rodzaju skale tworzone przez pracowników szkół dla niesłyszących, opracowywane na użytek tych placówek. Przykładem skali obserwacyjnej przygotowanej w ramach programu edukacji wczesnoszkolnej w Kalifornijskiej Szkole dla Głuchych (California School for the Deaf) we Fremont (USA) jest ASL Development Observation Record [10].

Poza skalami obserwacyjnymi stworzonymi z myślą o monitorowaniu rozwoju dzieci w zakresie nabywania kompetencji komunikacyjnych w językach migowych, istnieją również narzędzia, które obejmują oceną całościowe funkcjonowanie językowe dziecka (wszystkie wykorzystywane przez nie kody językowe). Przykładem tego typu skali jest Language Proficiency Profile-2 (LPP-2) opracowana przez J. Bebko oraz E. MacKinnon. Za pomocą LPP-2 oceniane są ogólne umiejętności porozumiewania się dziecka (z uwzględnieniem wszystkich wykorzystywanych przez nie sposobów komunikacji - języka migowego, gestów, języka angielskiego itp.).

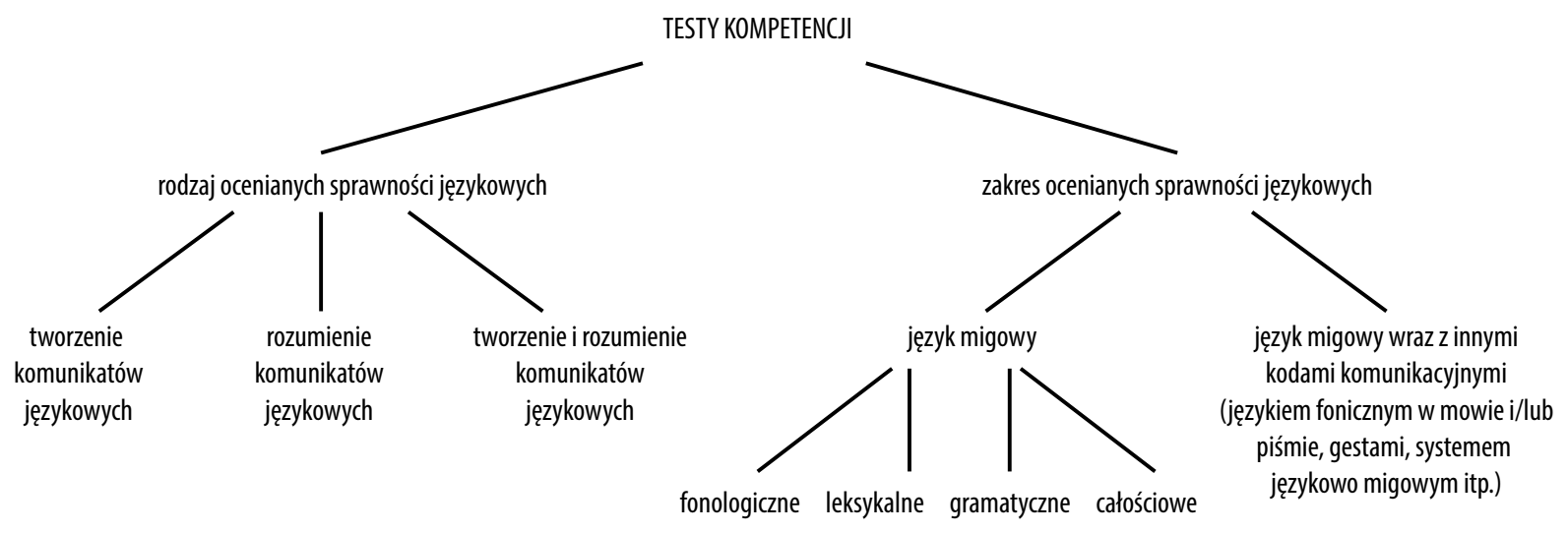

Rysunek 1. Podział testów do oceny poziomu kompetencji w językach migowych z uwagi na rodzaj i zakres ocenianych sprawności językowych. Źródło: Opracowanie własne.

Figure 1. Classification of sign-language linguistic proficiency tests depending on their type and the scope of the assessed language skills. Source: Own study. 
LPP-2 stanowi adaptację Kendall Communicative Proficiency Scale i składa się z listy prostych pytań. Wypełniany jest przez osobę pozostającą w stałym kontakcie z dzieckiem. Poszczególne pozycje skali odnoszą się do pięciu obszarów językowego funkcjonowania dziecka: (1) stopnia złożoności przekazywanych przez nie komunikatów pod względem ich budowy strukturalnej (ang. form) oraz (2) zakresu treściowego (ang. content); (3) okoliczności, w których posługuje się ono komunikatami językowymi (ang. use); (4) umiejętności formułowania wypowiedzi nieodnoszących się w sposób bezpośredni do sytuacji, w której się ono w danym momencie znajduje (ang. references) i (5) zdolności do uwzględniania perspektywy rozmówcy w trakcie prowadzenie konwersacji (ang. cohesion). Kolejność pytań została ustalona zgodnie $\mathrm{z}$ przewidywanymi (na podstawie literatury przedmiotu i konsultacji ze specjalistami) etapami rozwoju językowego dziecka. LPP-2 nie jest jednak skalą znormalizowaną. Mimo tego, podobnie jak opisane wcześniej narzędzia, umożliwia śledzenie czynionych przez dziecko postępów w zakresie umiejętności wyrażania i przekazywania własnych myśli i uczuć w języku migowym. Ponadto tego typu narzędzie może być wykorzystywane do prowadzenia badań, których celem jest porównywanie tempa nabywania poszczególnych sprawności językowych (z uwzględnieniem różnych kodów komunikacyjnych) przez uczniów o zróżnicowanych preferencjach w zakresie sposobów porozumiewania się [11].

\section{Testy kompetencji}

Drugą grupę opracowywanych obecnie narzędzi do oceny znajomości języków migowych u dzieci stanowią testy kompetencji. W porównaniu ze skalami obserwacyjnymi mają one bardziej sprecyzowany zakres mierzonych umiejętności, ponieważ bazują na niezmiennym materiale testowym. W przeciwieństwie do omówionych skal obserwacyjnych, w przypadku testów kompetencji podstawą do oceny poziomu funkcjonowania językowego dziecka nie jest jedynie obserwacja prowadzona przez osoby $z$ jego najbliższego otoczenia, ale także osiągane przez dziecko wyniki w konkretnych próbach testowych.

Opracowane do tej pory narzędzia są bardzo różnorodne. W zachodnim kręgu kulturowym najwięcej powstaje ich w: Stanach Zjednoczonych, Niemczech, Wielkiej Brytanii, Holandii i Szwecji. Można je podzielić na grupy $\mathrm{z}$ uwagi na różne kryteria, takie jak na przykład rodzaj i zakres ocenianych za ich pomocą sprawności językowych (rysunek 1).

$\mathrm{Na}$ potrzeby niniejszego opracowania, z uwagi na rodzaj ocenianych sprawności językowych, zaproponowano ogólny podział dostępnych testów na badające umiejętność: rozumienia (np. British Sign Language Receptive Skill Test, BSL-RST) [12], tworzenia (np. British Sign Language Production Test, BSL-PT) [13], rozumienia i tworzenia (np. Test of American Sign Language, TASL) [14] komunikatów w języku migowym.

Testy do dokonywaniu oceny poziomu rozumienia komunikatów w języku migowym składają się najczęściej z szeregu pytań zamkniętych. W przypadku testów wydanych w formie płyt DVD wraz z zeszytem testowym, takich jak BSL-RST, zadanie dziecka polega najczęściej na obejrzeniu krótkiego materiału wideo $\mathrm{z}$ zaprezentowaną wypowiedzią w języku migowym i dobraniu do niej odpowiedniej ilustracji wybieranej spośród trzech lub czterech obrazków znajdujących się w książeczce testowej [12]. Z kolei w przypadku testów w formie aplikacji komputerowej istnieje o wiele więcej możliwości tworzenia kafeterii odpowiedzi, które mogą mieć na przykład formę krótkich filmów w języku migowym, tak jak ma to miejsce np. w przypadku Computer-based Test for German Sign Language (CTDGS), Web-based British Sign Language Vocabulary Test (BSL-VT), a nie tylko statycznych ilustracji [15].

W przeciwieństwie do testów badających stopień rozumienia komunikatów w języku migowym narzędzia umożliwiające dokonywanie oceny sprawności tworzenia komunikatów w tym języku składają się głównie z zadań otwartych. Większość tego typu narzędzi bazuje na zadaniach wymagających od dzieci tworzenia własnej narracji na podstawie zaprezentowanego materiału testowego na przykład w formie filmu (tak jak w przypadku British Sign Language Production Test, BSL-PT) [13]. Dodatkowo pojawiają się również zadania wymagające od badanych dzieci zaangażowania się w konwersację z diagnostą lub innym dzieckiem (tak jak w przypadku American Sign Language Proficiency Assessment, ASL-PA) [16]. W każdym ze wspomnianych przypadków osoba oceniająca wypowiedzi dziecka powinna posiadać dużą biegłość w posługiwaniu się językiem migowym i ściśle kierować się wytycznymi sformułowanymi przez autorów poszczególnych narzędzi.

Zdecydowana większość powstałych do tej pory testów oceniających poziom kompetencji w zakresie języka migowego służy jednak do badania zarówno sprawności rozumienia, jak i tworzenia komunikatów językowych. Składają się one z szeregu zadań w formie pytań otwartych (wymagających najczęściej budowania różnego typu narracji) i zamkniętych (ograniczających się do testów jedno- lub wielokrotnego wyboru). Zdarza się, że zadania wychodzą poza ten schemat - na przykład w teście Aachen Tests zur Basiskompetenz in Deutscher Gebärdensprache (ATG) badane dzieci mają za zadanie odegrać za pomocą lalek treść nagranych na filmach komunikatów w języku migowym [17]. Z kolei w Web-based British Sign Language Vocabulary Test jedno z zadań wymaga od osób badanych samodzielnego podania znaku o podobnym znaczeniu do tego zaprezentowanego im $\mathrm{w}$ materiale filmowym [15]. Tego rodzaju narzędzia są zatem o wiele bogatsze pod względem typów składających się na nie zadań.

Opracowane do tej pory testy do oceny kompetencji w językach migowych można także pogrupować według zakresu ocenianych za ich pomocą sprawności językowych (rysunek 1) i wyodrębnić dwie główne podgrupy narzędzi:

- testy przeznaczone do oceny sprawności językowych w zakresie języka migowego,

- testy przeznaczone do oceny sprawności językowych w zakresie języka migowego wraz $\mathrm{z}$ innymi kodami 
komunikacyjnymi (językiem fonicznym w mowie i/lub piśmie, gestami, system językowo-migowym itp.).

Z kolei narzędzia służące do oceny kompetencji językowych w zakresie tylko i wyłącznie języka migowego można podzielić na cztery kategorie testów:

- fonologiczne, np. American Sign Language Phonological Awareness Test - ASL-PAT [18],

- leksykalne, np. Web-based British Sign Language Vocabulary Test - BSL-VT [15],

- gramatyczne, np. Test of American Sign Language - TASL [14],

- całościowe, np. Testbatterij voor de Nederlandse Gebarentaal - TNGT [19].

\section{Testy fonologiczne}

Głównym celem konstruowania testów fonologicznych ${ }^{1}$ jest badanie poziomu świadomości fonologicznej dziecka, a więc uzyskanie odpowiedzi na pytanie, czy jest ono w stanie różnicować znaki, które są do sobie podobne pod względem wizualnym, czyli wykonuje się je za pomocą takiego samego lub podobnego układu dłoni i/lub w zbliżonej lokalizacji, czy też za pomocą podobnego rodzaju ruchu. Przykładem tego typu narzędzia jest ASL-PAT, nad którym prace toczyły się w Minerva Deaf Research Lab na kanadyjskim Uniwersytecie Alberty w Edmonton. Celem badań prowadzonych $\mathrm{z}$ wykorzystaniem wspomnianego narzędzia było dokonanie oceny poziomu świadomości fonologicznej dzieci w wieku 4-8 lat w zakresie ASL. Zadania składające się na ASL-PAT wymagały od dzieci wskazywania znaków podobnych pod względem wyróżnionych parametrów (np. takich, które wykonuje się za pomocą tego samego układu dłoni i za pomocą tego samego ruchu, ale w innej lokalizacji) [18].

Inną propozycję testu fonologicznego stanowi szwedzki Cross-modal Phonological Awareness Test (C-PhAT-SSL) ${ }^{2}$ opracowany na potrzeby szerszego projektu badawczego poruszającego tematykę związku między świadomością fonologiczną (w języku szwedzkim i szwedzkim języku migowym) a poziomem rozumienia czytanych tekstów. Zadaniem dzieci badanych za pomoca C-PhAT-SSL jest różnicowanie znaków pochodzących ze szwedzkiego alfabetu palcowego oraz liczebników. W odróżnieniu od autorów ASL-PAT twórcy CPhAT-SSL wyszli z założenia, że to przede wszystkim kształt dłoni jest parametrem, który wpływa na rozpoznanie znaczenia znaku języka migowego, dlatego też wszystkie składające się na test zadania polegają na różnicowaniu tego parametru [21].

\footnotetext{
${ }^{1} \mathrm{~W}$ większości aktualnych opracowań dotyczących fonologii wizualnej języka migowego wyróżnia się trzy parametry składające się na znak migowy: konfigurację ręki (nazywaną również układem dłoni), lokalizację (miejsce lub miejsca na ciele, w którym/których wykonuje się dany znak) oraz rodzaj wykonywanego ruchu. Niektórzy badacze wskazują również, że takie niemanualne sygnały, jak ekspresja twarzy, ruchy ciała, głowy i oczu, charakterystyczne ruchy ust itp., powinny być również traktowane jako integralna część słów migowych [20].

${ }^{2}$ Test został skonstruowany przez szwedzki zespół, jednak w literaturze przedmiotu funkcjonuje on pod angielską nazwą. Autorce artykułu nie udało się dotrzeć do jego szwedzkiej nazwy.
}

\section{Testy leksykalne}

Drugą z wymienionych kategorii testów służących do oceny sprawności językowych w zakresie tylko i wyłącznie języka migowego stanowią testy leksykalne. Przykładem tego typu testu jest BSL-VT. Celem badania przeprowadzonego za jego pomoca jest dokonanie oceny poziomu znajomości leksyki w zakresie brytyjskiego języka migowego (ang. British Sign Language, BSL). Do tej pory badania wykonywane za pomocą tego narzędzia obejmowały dzieci w wieku od 4 do 17 lat. BSL-VT składa się z czterech typów zadań:

I typ: Rozumienie znaczenia znaku (ang. meaning recognition). Zadanie testowe polega na wskazaniu obrazka odpowiadającego swoim znaczeniem znakowi języka migowego - wyświetlany jest jedenen znak języka migowego i cztery obrazki.

II typ: Rozpoznanie adekwatnego znaczeniowo znaku (ang. form recognition) - zadanie testowe polega na wskazaniu znaku odpowiadającego swoim znaczeniem obrazkowi - wyświetlany jest jeden obrazek i cztery znaki języka migowego.

III typ: Przywołanie adekwatnego znaczeniowo znaku (ang. form recall) - zadanie testowe polega na samodzielnym zamiganiu znaku odpowiadającego swoim znaczeniem wyświetlonemu obrazkowi.

IV typ: Przywołania znaku o podobnym znaczeniu (ang. meaning recall) - zadanie testowe polega na samodzielnym zamiganiu znaku języka migowego o podobnym znaczeniu do wyświetlonego wcześniej znaku.

W każdym typie zadań wykorzystany został ten sam zestaw słownictwa. Autorzy BSL-VT wyszli bowiem z założenia, że dane słowo można znać na wielu różnych poziomach. Dokonując wyboru słów migowych wykorzystanych w BSL-VT, jego twórcy korzystali między innymi z zebranych do tej pory danych dotyczących określenia momentu, w którym głuche dzieci komunikujące się w BSL zaczynają posługiwać się poszczególnymi znakami. Inspirowali się także wyborem słownictwa użytego w niemieckim teście do oceny poziomu znajomości słownictwa zarówno w niemieckim języku migowym (niem. Deutsche Gebärdensprache, DGS), jak i języku niemieckim (w mowie oraz piśmie) - Prüfverfahren zur Erfassung lexikalisch-semantischer Kompetenz (PERLESKO) oraz różnych testach przeznaczonych do sprawdzania poziomu znajomości leksyki w języku angielskim. Konsultowali się oni także z głuchymi użytkownikami BSL, innymi badaczami oraz surdopedagogami.

W przypadku zadań zamkniętych, wymagających wybrania jednej odpowiedzi z czterech możliwości, wprowadzono trzy typy dystraktorów:

- fonologiczne - znak języka migowego jest podobny do prawidłowej odpowiedzi pod względem jednego lub więcej parametrów, takich jak: lokalizacja, ruch itp.,

- semantyczne - znak języka migowego niesie za sobą znaczenie podobne do tego, które jest w prawidłowej odpowiedzi, 
- niezwiązane - znak języka migowego nie jest w ogóle powiązane z prawidłową odpowiedzią [15].

\section{Testy gramatyczne}

Trzecią kategorię testów przeznaczonych do oceny sprawności językowych w zakresie tylko i wyłącznie języka migowego stanowią testy gramatyczne. Najczęściej składają się na nie zadania otwarte i zamknięte. Przykładowe typy zadań otwartych to:

- opisywanie treści obrazków,

- referowanie treści: historyjki obrazkowej, obejrzanej bajki lub historyjki (opowiedzianej w języku migowym),

- odpowiadanie na pytania dotyczące obejrzanej historyjki (opowiedzianej w języku migowym).

Z kolei w przypadku zdecydowanej większości zadań zamkniętych osoba badana musi wybrać prawidłową odpowiedź z podanych (zazwyczaj czterech) możliwości, np. wskazać, która z ilustracji najlepiej oddaje treść zamiganego zdania.

Interesującym przykładem narzędzia zawierającego wszystkie wymienione wyżej typy zadań jest Test of American Sign Language (TASL). Test ten został opracowany w ramach szerszego projektu badawczego, którego celem było uzyskanie odpowiedzi na pytanie, czy istnieje związek między posiadanym przez uczniów (w wieku 8-15 lat) poziomem sprawności językowej w zakresie tworzenia i rozumienia komunikatów w języku migowym a ich sprawnością w zakresie posługiwania się językiem angielskim w piśmie. TASL jest podzielony na dwie części. Pierwsza z nich jest przeznaczona do sprawdzania umiejętności tworzenia komunikatów w ASL i składają się na nią dwa typy zadań:

- umiejętność posługiwania się konstrukcjami klasyfikatorowymi ${ }^{3}$ (ang. Classifier Production Test): osoba badana ogląda trwający pięć minut film animowany, który jest jej wyświetlany najpierw w całości, a następnie w dziesięciu fragmentach. Następnie zadaniem ucznia jest streszczenie w języku migowym każdego z kolejnych fragmentów filmu. Wypowiedzi osób badanych są oceniane głównie pod względem poprawności zastosowanych konstrukcji klasyfikatorowych.

- umiejętność budowania narracji (ang. Sign Narrative): osoby badane zapoznają się z obrazkami pochodzącymi z książki dla dzieci i mają za zadanie opowiedzieć na ich podstawie historię. Wypowiedzi uczniów są oceniane pod kątem występowania $\mathrm{w}$ nich (określonych w przygotowanym wcześniej formularzu) różnego rodzaju struktur gramatycznych.

\footnotetext{
${ }^{3}$ „W językach migowych mianem klasyfikatorów określa się znaki zastępujące znaki rzeczownikowe. Każdy klasyfikator ma stały układ dłoni odpowiadający całej klasie rzeczowników jednego typu, np. jednolitych pod względem wyglądu, wielkości, kształtu itd." [22]. Z kolei konstrukcje klasyfikatorowe stanowią grupę struktur produktywnych, które - w oparciu o wspomniane wyżej klasyfikatory połączone ze znakami języka migowego służącymi do wyrażania relacji przestrzennych - pozwalają scharakteryzować różne właściwości opisywanego obiektu, takie jak jego kształt, sposób poruszania itp. [23].
}

Z kolei druga część TASL jest przeznaczona do oceny poziomu rozumienia komunikatów w ASL i zawiera cztery typy zadań:

- rozumienie narracji (ang. Story Comprehension) - osoba badana ogląda materiał wideo przedstawiający wypowiedź natywnego użytkownika ASL; w trakcie oglądania zaprezentowanego materiału badany uczeń musi odpowiadać na pytania dotyczące jego treści,

- rozumienie znaczenia konstrukcji klasyfikatorowych w kontekście narracyjnym (ang. Classifier Comprehension Test) - zadaniem osoby badanej jest wybranie jednego z pięciu filmów, w którym najtrafniej zostały opisane wszystkie cechy obiektu znajdującego się na zaprezentowanym im wcześniej obrazku,

- rozumienie określeń czasu (ang. Time Marker Test) - osoba badana musi zaznaczyć na karcie odpowiedzi (przypominającej kalendarz), do jakich dat odnoszą się zaprezentowane na filmach wypowiedzi,

- rozumienie określeń dotyczących relacji przestrzennych (ang. Map Marker Test) - osoba badana musi wybrać zdjęcia, które najlepiej oddają zaprezentowany na filmach opis relacji przestrzennych między różnymi obiektami (np. samochodami na drodze, meblami w sypialni itp.) [14].

\section{Testy całościowe}

Czwartą i ostatnią wyróżnioną grupę narzędzi do oceny znajomości języków migowych stanowią testy całościowe. Za ich pomocą badany jest szeroki wachlarz kompetencji w danym języku migowym. Różnią się one jednak od siebie znacząco pod względem struktury i liczby badanych obszarów funkcjonowania językowego. Niektóre z nich, jak na przykład Testbatterij Nederlandse Gebarentaal (TNGT) [19], są na tyle kompleksowe, że można za ich pomocą ocenić poziom kompetencji badanego zarówno w zakresie fonologii, leksyki i gramatyki. W innych, takich jak np. American Sign Language Assessment Instrument (ASLAI), autorzy skupiają się tylko na gramatyce i leksyce [17]. Poziom znajomości fonologii i leksyki jest najczęściej sprawdzany za pomocą zadań podobnych do wykorzystywanych w opisanych wyżej testach (ASL-PAT, CPhAT-SSL czy BSL-VT). Z kolei zadania sprawdzające znajomość gramatyki cechują się dużą różnorodnością, czego przykładem jest TASL.

Przedstawiając narzędzia do oceny znajomości języków migowych, nie można pominąć również testów umożliwiających badanie sprawności tworzenia i rozumienia komunikatów nie tylko w zakresie danego języka wizualno-przestrzennego, lecz także innych kodów komunikacyjnych. Do tego typu narzędzi należą: wspomniany wcześniej PERLESKO [24] oraz Profile of Multiple Language Proficiencies (PMLP) [25]. PERLESKO jest stosunkowo prostym i łatwym w użyciu narzędziem, które zostało stworzone w celu monitorowania rozwoju językowego niesłyszących dzieci (w zakresie leksyki) jednocześnie w niemieckim języku migowym (DGS) oraz języku niemieckim w mowie i piśmie. Test ma trzy części i składa się z pytań zamkniętych jednokrotnego wyboru. Zadania badanego ucznia polegają na: wyborze jednego spośród czterech obrazków, który odpowiada treści/znaczeniu zarówno prezentowanego badanemu znaku 
migowego, jak i wypowiadanego w języku niemieckim słowa. Ponadto badana osoba (dziecko/uczeń) ma za zadanie wybrać jedno z czterech napisanych w języku niemieckim słów i dopasować je do przedstawionego obrazka [24]. Z kolei PMLP charakteryzuje się większym poziomem złożoności niż PERLESKO. Zgodnie z założeniami jego twórców ma on służyć do przekrojowej oceny umiejętności tworzenia przez jednostkę komunikatów w języku angielskim, ASL i miganych odmianach języka angielskiego (ang. signed English) ${ }^{4}$. Badanie składa się z trzech typów zadań:

- testu szybkiego nazywania,

- rozmowy na tematy bliskie dziecku, związane $\mathrm{z}$ jego hobby, życiem rodzinnym, preferencjami komunikacyjnymi itp.,

- opowiadania historii na podstawie zaprezentowanych historii obrazkowych.

W trakcie trwania spotkania diagnostycznego dziecko może komunikować się z osobą przeprowadzającą badanie w dowolny, najbardziej dogodny dla siebie sposób. Z kolei osoba prowadząca badanie jednocześnie mówi i miga. Całe spotkanie diagnostyczne jest filmowane. Następnie wypowiedzi ucznia są analizowane pod kątem poziomu ich złożoności według przygotowanych wcześniej arkuszy oceny w podziale na komunikaty sformułowane w ASL i miganych odmianach języka angielskiego [25].

\section{Podsumowanie}

Począwszy od lat 90. XX wieku wśród badaczy można zaobserwować stopniowy wzrost zainteresowania problematyką konstruowania narzędzi do oceny rozwoju językowego dzieci posługujących się językiem migowym. Powstające narzędzia są bardzo różnorodne, zarówno pod względem poziomu złożoności, jak i zakresu możliwej do przeprowadzenia za ich pomocą diagnozy. Niestety obecnie większość prowadzonych prac pozostaje na etapie badań naukowych, których celem jest m.in. weryfikowanie wstępnych hipotez dotyczących możliwych sposobów konstruowania funkcjonalnych narzędzi diagnostycznych i nie są one wdrażane do codziennej praktyki diagnostycznej. W 2016 r. T. Hauga, W. Mann, E. Boers-Visker, J. Contreras, Ch. Enns, R. Herman oraz K. Rowley opracowali zestaw wytycznych, jakimi należy

\footnotetext{
${ }^{4}$ Pod pojęciem signed English twórcy PMLP rozumieją całą grupę systemów językowo-migowych (ang. manuals codes of English) funkcjonujących w oparciu o język angielskich, takich jak: Seeing Essential English, Signing Exact English, Linguistics of Visual English i Signed English modes [25]. Głównym założeniem twórców tych systemów jest idea wykorzystywania języka migowego jako uzupełnienia mowy fonicznej. Osoba nadajaca za ich pomoca komunikaty ma za zadanie jednocześnie mówić i migać. Wykorzystywane w formułowaniu komunikatów znaki pochodza z ASL, ale są one uzupełnione o znaki mające stanowić ilustrację struktur gramatycznych występujących w języku angielskim i niewystępujących w ASL. Szyk wypowiedzi jest zawsze zgodny z zasadami gramatyki angielskiej. Poszczególne wymienione systemy językowo-migowe różnią się od siebie m.in. pod względem oczekiwanego poziomu dokładności w przekazywaniu wszystkich elementów składających się na komunikat $\mathrm{w}$ języku angielskim za pomoca znaków języka migowego. Jedynie w części $\mathrm{z}$ nich dopuszczalne jest włączanie do wypowiedzi sygnałów mimicznych i elementów niemanualnych (takie jak np. wychylenia ciała, zmiany kierunku patrzenia itp.) [26].
}

się kierować, konstruując narzędzia do oceny znajomości języków migowych ${ }^{5}$ :

1. Korzystanie z pomocy natywnych użytkowników języka migowego na każdym etapie pracy nad narzędziem (począwszy od jego konstruowania, a skończywszy na rozpowszechnianiu). Do współpracy najlepiej jest włączać natywnych użytkowników języka migowego, którzy posiadają przygotowanie do tego typu pracy (np. akademickie) lub doświadczenie w tym zakresie. Zalecenie to jest szczególnie ważne w przypadku języków migowych, które nie zostały dokładnie zbadane i opisane. Ponadto informacje zwrotne od natywnych użytkowników języka migowego są potrzebne, aby upewnić się, że poszczególne pozycje testowe w sposób adekwatny oddają strukturę danego języka migowego.

2. Angażowanie niesłyszących i słyszących specjalistów $\mathrm{z}$ różnych dziecin - lingwistów psychologów, doświadczonych tłumaczy, specjalistów od tworzenia multimediów, programistów komputerowych (w przypadku chęci stworzenia aplikacji internetowej/mobilnej).

3. Przygotowywanie pomocy testowych adekwatnych do wieku osób testowanych, przejrzystych i dostępnych dla grupy docelowej. Unikanie materiałów zbytnio obciążających pamięć. Nie należy też oczekiwać odpowiedzi w formie pisemnej.

4. Dostosowanie do potrzeb grupy docelowej (dorosłych, dzieci itp.): czasu prezentowania materiału testowego, formatu poszczególnych pozycji testowych oraz sposobu przeprowadzania badania.

5. Dostosowanie do potrzeb grupy docelowej zawartości treściowej poszczególnych pozycji testowych (np. obrazki, które są odpowiednie dla dorosłych, mogą nie być właściwe dla dzieci).

6. Sformułowanie wskazówek, poleceń w testach i podręczniku w języku w pełni zrozumiałym dla wszystkich osób w populacji osób badanych, z uwzględnieniem ich zróżnicowania kulturowego i regionalnego.

7. W przypadku dokonywania adaptacji testu osoby odpowiedzialne za jej przeprowadzenie powinny się upewnić, że uwzględniły wszystkie różnice językowe i kulturowe pomiędzy populacją, dla której powstała pierwotna wersja narzędzia, a grupą, dla której tworzona jest jego adaptacja [27].

Przytoczone wytyczne nie stanowią oficjalnie obowiązującej wykładni w procesie konstruowania narzędzi do oceny znajomości języków migowych, jednak można je potraktować jako ważny krok w kierunku wypracowywania standardów mogących obowiązywać w procesie tworzenia tego typu narzędzi. Ponadto należy mieć nadzieję, że z biegiem lat zainteresowanie tą problematyką będzie wzrastać i w rezultacie udostępnione zostaną rzetelne narzędzia charakteryzujące się dobrymi parametrami psychometrycznymi, ponieważ tego typu narzędzia były, są i będą potrzebne wszędzie tam, gdzie mieszkają i uczą się osoby niesłyszące - szczególnie dzieci.

\footnotetext{
${ }^{5}$ Wytyczne zostały opracowane jako podsumowanie dyskusji, która miała miejsce w trakcie międzynarodowych warsztatów pt. „Wyzwania metodologiczne i innowacje technologiczne w dokonywaniu oceny znajomości języków migowych", które odbyły się w Zurychu w 2015 roku i zostały sfinansowane ze środków Swiss National Science Foundation (SNSF) [27].
} 


\section{Piśmiennictwo}

1. Marschark M, Wauters L, Cognitive functioning in deaf adults and children. W: Marschark M, Spencer PE (red.). The Oxford Handbook of Deaf Studies, Language, and Education, Volume 1 (2 ed.), New York: Oxford University Press; 2011, s. 487-499.

2. Mann W, Prizn PM. An investigation of the need for sign language assessment in deaf education. Am Ann Deaf, 2006; 151(3): 356-370.

3. Sign language assesment instrument, http://signlang-assessment. info (dostęp: 28.12.2017).

4. Kotowicz J, Kielar-Turska M, Woll B, Herman R, Łacheta J, Schromová M. The adaptation of British Sign Language (BSL) Receptive Skills Test into Polish Sign Language (PJM). Conference Poster: 2nd International Conference on Sign Language Acquisition, Amsterdam, Holand, https://www.researchgate.net/profile/Justyna_Kotowicz2/publication/311921347_The_adaptation_ of_British_Sign_Language_BSL_Receptive_Skills_Test_into_ Polish_Sign_Language_PJM/links/586272fb08ae6eb871ab1899/ The-adaptation-of-British-Sign-Language-BSL-Receptive-SkillsTest-into-Polish-Sign-Language-PJM.pdf (dostęp: 30.12.2017).

5. Wiśniewska-Jankowska A. Test do Oceny Znajomości Leksyki w Polskim Języku Migowym (TOZL PJM) - Konstrukcja i charakterystyka psychometryczna. Studia Psychologiczne, 2016, 54: $17-29$.

6. Simms L, Baker S, Clark MD. Visual Communication and Sign Language Checklist for Deaf and Hard of Hearing Children. Washington DC: Gallaudet University Press; 2013.

7. Visual Communication and Sign Language Checklist: Online (VCSL:O) Part of the VL2 Online Assessment System, http:// vl2.gallaudet.edu/files/3414/9444/7372/VCSL_brochure2017. pdf (dostęp: 13.12.2017).

8. Anderson D, Reilly J. The MacArthur Communicative Development Inventory: normative data for American sign language. J Deaf Stud Deaf Educ, 2002; 7(2): 83-119.

9. Kip P. The comparability of language assessment instruments for Sign Language of the Netherlands, the NGT-OP and the T-NGT - Master Thesis Linguistics. Amsterdam: University of Amsterdam; 2009.

10. ASL Stages of Development, https://successforkidswithhearingloss. com/wp-content/uploads/2011/12/ASL-Stages-of-DevelopmentAssmt.pdf (dostęp: 28.02.2018).

11. Bebko JM, Calderon R, Treder R. The Language Proficiency Profile-2: assessment of the global communication skills of deaf children across languages and modalities of expression. J Deaf Stud Deaf Educ, 2003; 8(4): 438-51.

12. Haug T. Review of sign language assessment instruments. W: Baker AE, Woll B (red.). Sign language acquisition. Amsterdam: John Benjamins Publishing Company; 2008, s. 51-85.

13. Herman R, Rowley K, Marshall C, Mason K, Atkinson J, Woll B i wsp. Profiling SLI in deaf children who are sign language users. W: Quinto-Pozos D (red.). Signed Language Communication and Disorder. Bristol: Multilingual Matters; 2014, s. 45-69.
14. Strong M, Prinz PM. A study of the relationship between American sign language and English literacy. J Deaf Stud Deaf Educ, 1997 (Winter); 2(1): 37-46.

15. Mann W, Marshall C. Investigating deaf children's vocabulary knowledge in British sign language. Language Learning, 2011; 62(4): 1024-51.

16. Maller S, Singleton J, Supalla S, Wix T. The development and psychometric properties of the American sign language proficiency assessment (ASL-PA). J Deaf Stud Deaf Educ, 1999; 4(4): 249-269.

17. Haug T. Review of sign language assessment instruments. W: Baker AE, Woll B (red.). Sign language acquisition. Amsterdam: John Benjamins Publishing Company; 2008, s. 51-85.

18. Enns Ch, Haug T, Herman R, Mann W, McQuarrue L. Exploring ign langauge assessment tools in Europe and North America. W: Marschark M, Lampropoulou V, Skordilils E (red.). Diversity in Deaf Education. New York: Oxford University Press; 2016, s. 171-218.

19. Hermans D, Knoors H, Verhoeven L. Assessment of sign language development: the case of deaf children in the Netherlands. J Deaf Stud Deaf Educ, 2010; 15(2): 107-119.

20. Tomaszewski P. Fonologia wizualna. Warszawa: MATRIX; 2010.

21. Holmer E, Heimann M, Rudner M. Evidence of an association between sign language phonological awareness and word reading in deaf and hard-of-hearing children. Res Dev Disabil, 2016; 48: 145-159.

22. Linde-Usiekniewicz J, Łozińska S. Predykacje klasyfikatorowe jako problem lingwistyczny i leksykograficzny. W: Rutkowski P (red.). Ikoniczność w gramatyce i leksyce polskiego języka migowego (PJM). Warszawa: Wydział Polonistyki Uniwersytetu Warszawskiego; 2017, s. 171-204.

23. Filipczak J. Anotacja korpusu PJM. W: Rutkowski P (red.). Lingwistyka przestrzeni i ruchu. Komunikacja migowa a metody korpusowe. Warszawa: Wydział Polonistyki Uniwersytetu Warszawskiego; 2014, s. 91-106.

24. Perlesko: Vocabulary test for German Sign Language, http:// www.signlang-assessment.info/index.php/perlesko-vocabularytest-for-german-sign-language.html (dostęp: 28.12.2017).

25. Goldstein G, Bebko JM. The Profile of Multiple Language Proficiencies: a measure for evaluating language samples of deaf children. J Deaf Stud Deaf Educ, 2013; 8(4): 452-63.

26. Spencer PE. It Seems Like Only Yesterday... W: Marschark M, Spencer PE (red.). The Oxford Handbook of Deaf Studies in Language. New York: Oxford University Press; 2016, s. 3-18.

27. Haug T, Mann W, Boers-Visker E, Contreras J, Enns C, Herman $\mathrm{R}$ i wsp. Guidelines for sign language test development, evaluation and use (dokument niepublikowany), http://signlang-assessment.info (dostęp: 17.12.2017). 
